\title{
The effect of different concentrations of Neem (Azadiractha indica) leaves extract on the inhibition of Streptococcus mutans (In vitro)
}

\author{
Sri Kavi Subramaniam, Widowati Siswomihardjo, and Siti Sunarintyas \\ Department of Biomaterials \\ Faculty of Dentistry Gadjah Mada University \\ Yogyakarta - Indonesia
}

\begin{abstract}
The Neem plant has a history for treating gum and teeth problems and this plant is used for oral care in India. The active component (Azadirachta indica) has been proven to exhibit antibacterial properties. The objective of this study was to determine the influence of different concentrations of Neem leaves extract on the inhibition of Streptococcus mutans. Neem leaves extract at concentrations of 10\%, 20\%, 40\%, 60\%, 80\%, and 100\% was prepared. Fifty milliliters of each concentration were dropped into holes of 6 millimeters in diameter on a MHA agar that has been inoculated with Streptococcus mutans. Distilled water was used as a control. After 24 hours of incubation, the inhibition diameters were measured and analyzed. The statistical results of the one-way analysis of variance (ANOVA) illustrated that the different concentrations of Neem extract had a significant influence on the inhibition of Streptococcus mutans. This was followed with the Least Significant Difference (LSD) which implied that there were significant differences between all the concentrations of Neem leaves extract used in this experiment. The conclusion of this study was that Neem leaves extract exhibited antibacterial effect towards Streptococcus mutans and different concentration of Neem leaves extract influenced the inhibition of Streptococcus mutans.
\end{abstract}

Key words: Azadirachta indica, Streptococcus mutans, antibacterial

Correspondence: Sri Kavi Subramaniam, Department of Biomaterials, Faculty of Dentistry Gadjah Mada University. Denta II, Sekip Utara Street Yogyakarta, Indonesia.

\section{INTRODUCTION}

Dental caries is one of the most common human diseases that affect the vast majority of individuals. Samaranayake ${ }^{1}$ defines caries as the localized destruction of tooth tissue by bacterial fermentation of dietary carbohydrates. Among the types present in the oral cavity, the cariogenic bacteria are the ones responsible for dental caries. ${ }^{1}$ The most common and most destructive bacteria are the Streptococcus mutans. ${ }^{2}$ Cross sectional and longitudinal epidemiology surveys have implicated Streptococcus mutans in the etiology of human dental caries. ${ }^{3}$

Streptococcus mutans can rapidly metabolize sugars to lactic acid and other organic acids, reducing $\mathrm{pH}$ and initializing enamel demineralization. ${ }^{4}$ Inhibiting the growth of the Streptococcus mutans in the oral cavity would lead to healthier teeth and gums. ${ }^{1}$ Manson and Aley ${ }^{4}$ also states that with the current soft civilized diet, teeth wear is slight or absent, thus encouraging bacterial deposition. ${ }^{2}$

As the public awareness for oral hygiene increases, many people are now turning to traditional medicine for a solution. The Neem tree originates from northeast India. 5 It is also known as Margosa or the Persian lilac. ${ }^{6}$ In Indonesia, this plant is referred to as Mimba. ${ }^{7}$ Over centuries, this plant has provided leaves, seed oil and barks as a range of healing properties. ${ }^{8}$ In India this plant is referred to as the village pharmacy because of its ability to cure many disorders ranging from bad teeth and bed bugs to ulcers and malaria. ${ }^{9}$ The Neem is of particular interest to the field of dentistry for it has a long history treating teeth and gum problems. ${ }^{9}$ In rural areas of India, the twigs are used as toothbrush to prevent gingivitis. ${ }^{10}$

In a study to determine the most effective method for reducing plaque formation and the level of bacteria on tooth surface, it was found that micro-organisms in inflamed gums are resistant to penicillin $(44 \%)$ and tetracycline $(30 \%)$ but were not resistant to antibacterial plant extracts like the Neem. ${ }^{11}$ In another report by the UCLA School of dentistry, it was found that Neem could reduce the ability of Streptococcal bacteria to colonize on the surface of teeth, thus providing an explanation for Neem's long-standing reputation as a cavity fighter. ${ }^{12}$ From the above, it is deduced that although the anti-bacterial effect of Neem has been proven, there is still a grey area concerning its effective concentration against the Streptococcus mutans specifically. The objective of this study is to determine the effectiveness of the Neem leaves extract as an anti-bacterial against the growth of Streptococcus mutans.

\section{MATERIALS AND METHOD}

This was a laboratory experimental study. The extractions of Neem leaves extract were carried out at the Traditional Medicine Research Center, Gadjah Mada University. The materials used in this experiment are Neem 
leaves aqueous extract $(10 \%, 20 \%, 40 \%, 80 \%$, and $100 \%)$, distilled water, Brain Heart Infusion (BHI) as a culture medium, Muller Hinton Agar (MHA) and Cultured Streptococcus mutans. Among the instruments used are Petri dishes (10 cm in diameter), test tubes, test tube rack, and water bath, sliding calipers, sterile loop, incubator, autoclave and micropipettes. One kilogram of matured and complete Neem leaves is selected. One litre of distilled water was added to the leaves and then it was blended in the blender. The mixture was put through a Buchner filter to separate the filtrate and the residue. The filtrate was then evaporated over a water-bath at $60^{\circ} \mathrm{C}$ to obtain concentrated extract. The extract was then ready for dilution. ${ }^{13}$ Based on previous experiments carried out by Satya ${ }^{14}$ and Pramularsih, ${ }^{15}$ in this study the concentrations of Neem leaves extract used are $10 \%, 20 \%, 40 \%, 80 \%$, and $100 \%$. Distilled water was used to dilute the Neem leaves extract and the various concentration of Neem leaves were prepared by the mass of extract per volume. The dilution details are presented below: Group A: for the control only $100 \mathrm{ml}$ of distilled water; Group B: for 10\%, $10 \mathrm{mg}$ of Neem leaves extract and distilled water added little by little to make the volume $100 \mathrm{ml}$; Group C: for 20\%, $20 \mathrm{mg}$ of Neem leaves extract and distilled water added little by little to make the volume $100 \mathrm{ml}$; Group D: for 40\%, $40 \mathrm{mg}$ of Neem leaves extract and distilled water added little by little to make the volume $100 \mathrm{ml}$; Group E: for $80 \%, 80 \mathrm{mg}$ of Neem leaves extract and distilled water added little by little to make the volume $100 \mathrm{ml}$; Group F: for $100 \%, 100 \mathrm{mg}$ of Neem leaves extract and distilled water added little by little to make the volume $100 \mathrm{ml}$.

The bacterial sensitivity test was carried out to determine the antibacterial effect of the Neem leaves extract. In this experiment the bacterial sensitivity test was carried out using the diffusion techniques. ${ }^{16}$ This technique was used by most laboratories to test routinely for bacterial sensitivity. The sample of Streptococcus mutans strain for this experiment was obtained from the Microbiology department of the Veterinary Faculty, Gadjah Mada University. The Streptococcus mutans was cultured on Mueller Hinton Agar. After 24 hours of incubation at $37^{\circ} \mathrm{C}, 5$ colonies were transferred into $2 \mathrm{ml}$ of Brain Heart Infusion (BHI). Its turbidity was compared to the standard Brown III solution. Using a sterile loop of about $4 \mathrm{~mm}$ in diameter, the suspension was inoculated three times on the centre of a MHA plate. A sterile cotton wool pad is then used to spread the inoculum evenly over the plate.

Six holes were then punctured on the MHA each six milimetres in diameter. Fifty microlitres extract of each concentration was dripped into holes. For the control, fifty microlitres of distilled water was used. Similarly, two other Petri dishes were prepared as well. After incubation for 24 hours at $37^{\circ} \mathrm{C}$, the inhibition zones are measured with a sliding caliper.
After 24 hours of incubation, the Petri dishes were observed for inhibition zones around each hole. This translucent area around the hole where there was no Streptococcus mutans growth is also referred to as the radical zone. The required area was from the edge of the hole to the outer border of bacterial inhibition. The diameter is measured using a sliding caliper with a precision of 0.01 $\mathrm{mm}$.

Each measurement was taken three times to ensure higher accuracy. The horizontal diameter of the inhibition zone was measured, followed by the vertical diameter and finally the diameter between the first two lines at an angle of $45^{\circ}$. The average of the three measurements for each zone was recorded. The procedure was repeated for all three Petri dishes. The results obtained were then systematically documented in a form of a table.

Statistical analysis of the data was carried out using the One-way analysis of variance (ANOVA). In this test, the calculated $\mathrm{F}$ ratio was compared to the value from the $\mathrm{F}$ distribution table at a confidence level of $95 \% .{ }^{17}$ ANOVA is to see if the different concentrations and control have a significant influence on the inhibition of Streptococcus mutans. The ANOVA was then followed by a post-hoc comparison, in this case, the Least Significant Difference (LSD). LSD was used to further speculate if there was a significant difference between the various concentrations. ${ }^{17}$

\section{RESULTS}

A line diagram is plotted to see the relationship between the inhibition diameters and extract concentrations. The chart shows that the increase of Streptococcus mutans inhibition diameter corresponds with the increase of Neem leaves extract concentration. The diagram representing these results is presented in figure 1 .

The data is first analyzed with the normality tests. The results of the test show that the probability is 0.85 . This value is greater then 0.05 , thus implying that the acquired data is normally distributed (table 1).

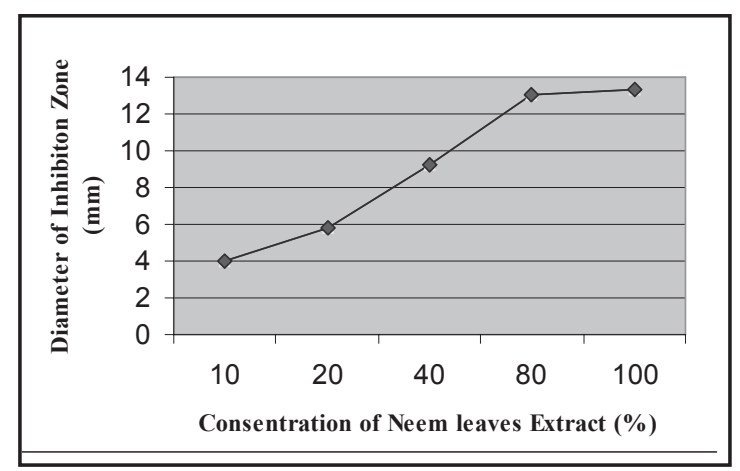

Figure 1. Relationship between the inhibition diameters of Streptococcus mutans and Neem leaves extract. 
Table 1. Statistical results of the normality test

\begin{tabular}{lccc}
\hline & \multicolumn{3}{c}{ Kolmogorov-Smirnov } \\
\cline { 2 - 4 } & & Df & Sig \\
\hline Radical Zone Diameters & 0.190 & 54 & 0.850 \\
\hline
\end{tabular}

The normality test is then followed by the ANOVA. In this test, the calculated $\mathrm{F}$ ratio is compared to the value from the $\mathrm{F}$ distribution table at a confidence level of $95 \%$. The ANOVA speculates if the different concentrations of Neem leaves extract have a significant influence on the inhibition of Streptococcus mutans. The results of this analysis are presented in table 2 .

Table 2. Statistical results of the One-way analysis of varience (ANOVA)

\begin{tabular}{cccccc}
\hline Source & Ss & Df & Ms & F & P \\
\hline $\begin{array}{c}\text { Between } \\
\text { Groups }\end{array}$ & 1255.568 & 5 & 251.114 & 6495.874 & 0.001 \\
$\begin{array}{c}\text { Within } \\
\text { Groups }\end{array}$ & 3328.267 & 48 & 0.038 & - & - \\
\hline Total & 68983.000 & 53 & - & - & - \\
\hline
\end{tabular}

The results of the ANOVA show that the probability is 0.001 ; this value is less than the 0.05 confidence level. The interpretations of the ANOVA illustrates that the different concentration of Neem leaves extract has a significant influence on the inhibition of Streptococcus mutans. To further speculate if there is a significant difference between the various concentrations, the ANOVA test is then followed by a post-hoc comparison, the Least Significant Difference (LSD). These results imply that there are significant differences between all the concentrations of Neem leaves extract used in this experiment (table 3 ).

Table 3. Least Significant Difference (LSD) statistical results

\begin{tabular}{lcc}
\hline Between Concentration & Mean Difference & Sig \\
\hline $10 \%$ and $20 \%$ & 1.7556 & 0.001 \\
$10 \%$ and $40 \%$ & 5.2000 & 0.001 \\
$10 \%$ and $80 \%$ & 9.0667 & 0.001 \\
$10 \%$ and $100 \%$ & 9.3111 & 0.001 \\
$20 \%$ and $40 \%$ & 3.4444 & 0.001 \\
$20 \%$ and $80 \%$ & 7.3111 & 0.001 \\
$20 \%$ and $100 \%$ & 7.5556 & 0.001 \\
$40 \%$ and $80 \%$ & 3.8667 & 0.001 \\
$40 \%$ and $100 \%$ & 4.1111 & 0.001 \\
$80 \%$ and $100 \%$ & 0.2444 & 0.011 \\
\hline
\end{tabular}

\section{DISCUSSION}

The results of this study exemplifies that the Neem leaves extract has antibacterial activity towards Streptococcus mutans. The inhibition area that is formed is larger as the concentration of Neem leaves extract is increased. The statistical analysis carried out using the ANOVA proves that the different concentrations have significant influence on the growth of Streptococcus mutans. These results also coincide with the results in the research of Satya ${ }^{14}$ and Pramularsih. ${ }^{15}$ Satya ${ }^{14}$ documented a study using Neem leaves to inhibit the growth of Bacillus subtilis and E. coli. Pranularsih ${ }^{15}$ on the other hand studied the influence of Neem leaves extract in the inhibition of Staphylococcus aureus and Salmonella typhi. Although the bacteria used in the both the experiment are different, all the results correspond with the theory that Azadiachtin the active component of Neem is of the phenol group and that phenols substances can destroy bacterial cell walls which will inevitably inhibit the growth of bacteria. ${ }^{18}$ The breakdown of cell wall disturbs osmotic pressure and leads to cell death. ${ }^{19}$

The statistical analysis summarized in table 2 proves that the different concentration of Neem leaves extract have a significant influence on the growth of Streptococcus mutans. In table 3 , the post hoc test shows that the probability between the concentration of $80 \%$ and $100 \%$ is 0.011 . Although this value is statistically significant, it is higher that the probability of all the other concentration. The different value confirms that there is less statistical difference between the concentration of $80 \%$ and $100 \%$. This gives evidence that the effectiveness of Neem leaves extract on the Streptococcus mutans at concentration $80 \%$ and $100 \%$ is clinically almost the same.

Nevertheless, it is still not viable to determine the effective concentration of the Neem leaves extract to inhibit the growth of Streptococcus mutans. The effective concentration is the concentration where beyond that value the inhibition diameter is constant or decreases. In this experiment it can only be approximated that the effective concentration is above $80 \%$. The value is indistinct hence, future experiments with a narrower range are necessary to determine the effective concentration of Neem leaves extract to inhibit the growth of Streptococcus mutans.

In this experiment, the Neem leaves are extracted using distilled water as the dissolvent, therefore the active component that is extracted is less. The use of organic dissolvent such as ethanol is more effective because theoretically the active component belongs to the phenol group and phenols would dissolve better in organic dissolvent. ${ }^{11}$ Ethanol extractions may also be able to show the effective concentration of Neem leaves extract in the inhibition of Streptococcus mutans which could not be determined in this experiment. However, ethanol extractions are more complicated and expensive, therefore in this study, distilled water is used as it is more economical.

From this study it can be concluded that the Neem leaves extract has antibacterial properties towards the Streptococcus mutans. This could be further developed as an alternative method to prevent caries. In this experiment, the extracting method has been kept simple without the use of ethanol and sophisticated methods. The experiment 
is performed keeping in mind that the ultimate aim is to find a cheaper and safe method to curb caries in developing countries.

\section{REFERENCES}

1. Samaranayake LP. Essential microbiology for dentistry. London: Churchill Livingstone; 2002. p. 121-6.

2. Marsh P, Martin MV. Oral microbiology. $4^{\text {th }}$ ed. USA: Reed Educational and Professional, Ltd; 1999. p. 82-100.

3. Willet PN, White RR, Rosen S. Essential dental microbiology. New Jersey: Appleton and Lange: Prentice Hall Inter Inc; 1991. p. 157-9.

4. Manson JD, Eley BM. Outline of periodontics. $4^{\text {th }}$ ed. USA: A Division of the Reed Educational and Professional, Ltd; 2000. p. 318-9.

5. Puri HS. Neem the divine tree (Azadiracthta indica). Netherlands: Harwood Academic Publishers; 1999. p. 182.

6. Backer CA, Bakhuizen, Brink RC. Flora of Java. Volume 2, NVP Nordhoff, Gronigen the Netherlands: NVP Nordhoff. 1965. p. 120.

7. Anonym. Medicinal herbs index in Indonesia. $2^{\text {nd }}$ ed. Jakarta: PT Eisai Indonesia; 1995. p. 168.

8. Duke JA. Chemicals and the biological activities in Azadirachta. 1992. Available at: http: //www.ars-grin.gov/cgi_bin/duke/ pharmacy/scroll.3.pl. Accessed December 15, 2004.

9. Narula AS. Neem: the tree of 1000 uses, Alpha Omega Labs. 1997. Available at: http: //www.altcancer.com./neem.1000.htm. Accessed January 10, 2005.
10. McCaleb R. Neem the ancient herb from India.1986. Available at: http: //www.altcancer.com./images/. Accessed December 20, 2004.

11. Wolinsky LE, Mania S, Nachnani S, Ling S. The inhibiting effect of Aqueous Azadirachta indica (Neem) extract upon bacterial properties influencing in-vitro plaque formation. J Dent Res 1996; 75:816-22.

12. Vanka A, Tandon S, Rao SR, Udupa N, Ramkumar P. The effect of Indigenous Neem (Azadirachta indica) mouth wash on Streptococcus mutans and Lactobacilli growth. Indian J Dent Res 2001; 12(3):133-44.

13. Wibowo S. Efektivitas antimalaria ekstrak biji Mimba (Azadirachta indica A.juss) pada Mencit (Swiss Mice). Skripsi. Yogyakarta: Fakultas Farmasi Universitas Gadjah Mada; 1990. h. 7-17.

14. Satya RCD. Daya antibakteri terhadap Bacillus subtilis dan E. colii daun dan kulit ranting tanaman Mimbo (Azadirachtin indica) serta profil kromatrografi lapis tipis dari fraksi aktif. Skripsi. Yogyakarta: Fakultas Farmasi, Universitas Gadjah Mada; 2000. h. 12-16

15. Pramularsih ED. Uji aktivitas antibakteri daun Mimba (Azadirachtin indica) terhadap Staphlylococcus aureus and Salmonella typhi berserta profil kromatografi lapis tipisnya. Skripsi. Yogyakarta: Fakultas Farmasi, Universitas Gadjah Mada. 2001. h. $9-15$.

16. Cheesbrough M. Medical laboratory manual for tropical countries. Volume II. England: Tropical Health Technology; 1984. p. 128.

17. Dawson B, Saunders, Trapp RG. Basic and clinical biostatistics. $2^{\text {nd }}$ ed. Norwalk, Connecticut: Appleton and Lange; 1994. p. 97.

18. Trewari DN. Monograph on Neem (Azadirachta indica). Dehra Dun, India: Int. Book Distributors; 1992. p. 179.

19. Robinson T. The organic constituens of higher plants. $6^{\text {th }}$ ed. Bandung: Penerbit ITB; 1995. p. 191-2. 